\title{
Cell Contact Regulates Fate Choice by Cortical Stem Cells
}

\author{
Robert Y. L. Tsai and Ronald D. G. McKay \\ Laboratory of Molecular Biology, National Institute of Neurological Disorders and Stroke, National Institutes of Health, \\ Bethesda, Maryland 20892
}

Cell fate is determined by intrinsic programs and external cues, such as soluble signals and cell-cell contact. Previous studies have demonstrated the roles of soluble factors in the proliferation and differentiation of cortical stem cells and cell-cell contact in maintaining stem cells in a proliferative state. In the present study, we focused on the effect of cell-cell interaction on cell-fate determination. We found that density could exert a strong influence on the cell-type composition when cortical stem cells differentiate. Multipotent stem cells, which normally gave rise to neurons, astrocytes, and oligodendrocytes under high-density culture condition, differentiated almost exclusively into smooth muscle at low density. Clonal analysis indicated that smooth muscle and astrocytes were derived from a common precursor and that the density effect on cell types used an instructive mechanism on the choice of fate rather than an effect of selective survival and/or proliferation. This instructive mechanism depended on the local and not the average density of the cells. This local signal could be mimicked by membrane extract. These findings demonstrate the importance of membrane-bound signals in specifying lineage and provide the first evidence for a short-range regulatory mechanism in cortical stem cell differentiation.

Key words: cortical stem cell; density; cell contact; cell-fate determination; smooth muscle; astrocyte
The ventricular zone cells in the developing brain undergo extensive cell division to generate diverse cell types. One key issue in developmental neurobiology is to understand how the brain orchestrates the differentiation of various cell types in a precise temporal and spatial order. One attractive model proposed that different cell types in the brain were generated from a common precursor in the developing CNS (Gage and Fisher, 1995; McKay, 1997; Murphy et al., 1997). Both in vivo fate-mapping studies (Sanes et al., 1986; Price et al., 1987; Luskin et al., 1988; Galileo et al., 1990; Williams et al., 1991; Walsh and Cepko, 1992) and in vitro clonal analysis of stem cell culture (Temple, 1989; Reynolds and Weiss, 1992; Reynolds et al., 1992; Kilpatrick and Bartlett, 1993; Temple and Davis, 1994; Johe et al., 1996) provided convincing evidence for the existence of self-renewing, multipotent stem cells in the developing neuroepithelium. These stem cells, isolated from rat embryonic day 10.5-14.5 (E10.5-E14.5) telencephalon, express the intermediate filament nestin (Lendahl et al., 1990) and undergo continuous cell division in the presence of basic fibroblast growth factor (bFGF) mitogen in vitro (Kilpatrick and Bartlett, 1993; Johe et al., 1996). Cloning of cortical stem cells in culture allows us to study their properties in detail, particularly their full developmental potential and the molecular mechanism underlying cell-fate determination.

Previous work has explored the phenotypic potential of neural stem cells in culture by inducing differentiation in the presence of various soluble factors. Several studies indicate that leukemia inhibitory factor (Richards et al., 1996; Koblar et al., 1998) or ciliary neurotrophic factor (CNTF) (Lillien and Raff, 1990; Johe et al., 1996) could promote astrocytic cell fate of stem cells by an instructive mechanism, whereas triiodothyronine (Johe et al., 1996) and insulin growth factors I and II (McMorris and Dubois-

Received Jan. 10, 2000; revised March 3, 2000; accepted March 9, 2000.

Correspondence should be addressed to Dr. Ronald D. G. McKay at the above address. E-mail: mckay@codon.nih.gov.

Copyright $\odot 2000$ Society for Neuroscience $0270-6474 / 00 / 203725-11 \$ 15.00 / 0$
Dalcq, 1988) favored an oligodendrocytic fate. Recent studies using stem cells isolated from rodent E10.5-E13.5 spinal cord (Mujtaba et al., 1998) or E14.5 cortex (Hazel et al., 1997) revealed an unexpected smooth muscle (SM) fate of CNS stem cells induced by bone morphogenic proteins (BMPs). In these studies, CNS stem cells could give rise to a p75/nestin immunoreactive neural crest stem cell-like transient population, which subsequently differentiate into peripheral neurons, smooth muscle, and Schwann cells in mass and clonal culture (Mujtaba et al., 1998). BMPs act instructively on fate choice between CNS stem cells and neural crest stem cells (Hazel et al., 1997). Despite the clear demonstration of the lineage relationship between CNS and PNS stem cells in vitro, the question remains whether CNS stem cells adopt smooth muscle fate in vivo after neural tube closure and, if they do, where do they reside and what are their physiological functions.

Signals coming from both diffusible factors and cell contact are essential for the normal development of neuroepithelium. Diff usible factors, such as Sonic hedgehog and BMPs, play crucial roles in normal pattern formation and cellular differentiation. The importance of cell-cell contact has been implicated in several key aspects of neural development. These include (1) maintaining cortical progenitor cells (Temple and Davis, 1994) and neuroblasts (Barakat et al., 1982; Gao et al., 1991; Ghosh and Greenberg, 1995) in division; (2) inducing morphological changes in astrocytes (Hatten, 1985, 1987); and (3) promoting synapse formation in neurons (Pfrieger and Barres, 1997). However, its effect on stem cell lineage determination remains unexplored. In this paper, we examined the effect of homotypic contact between cortical stem cells on cell-fate determination during seruminduced differentiation. We found that multipotent stem cells, which normally gave rise to neurons, astrocytes, and oligodendrocytes under high-density culture condition, differentiated almost exclusively into smooth muscle at low density. Using clonal analysis, we showed that an instructive mechanism, rather than 

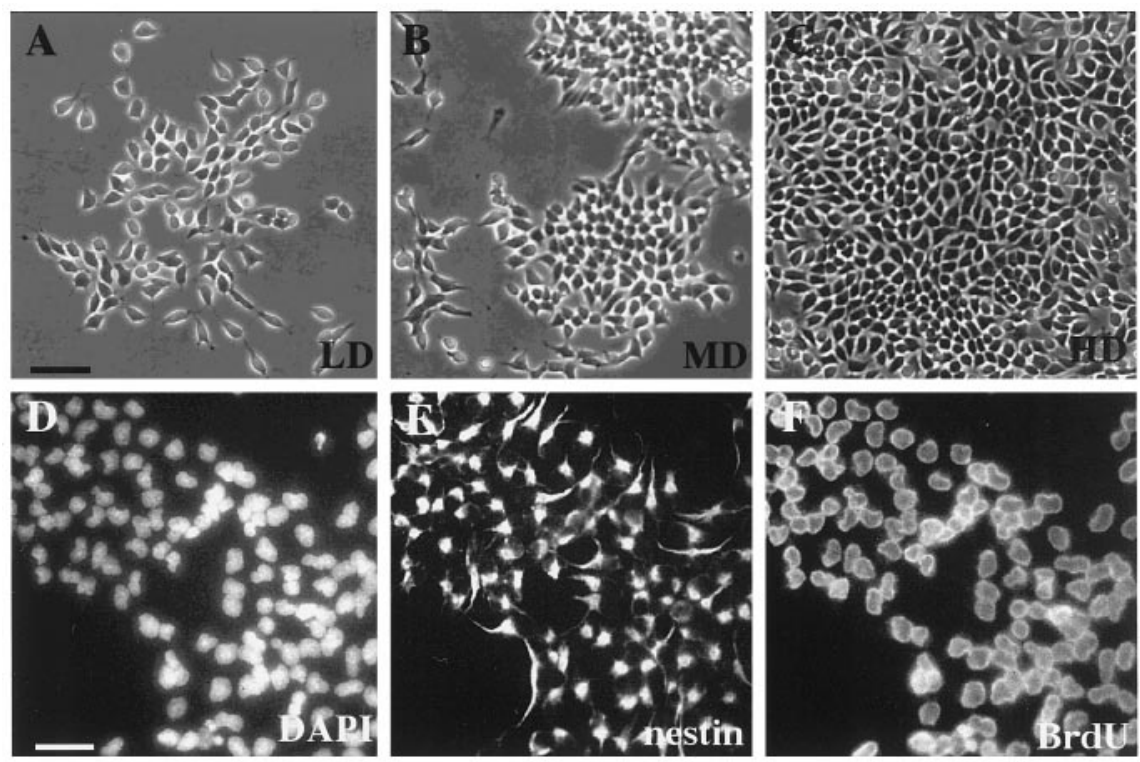

G

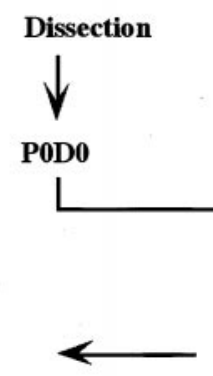
induced differentiation day 8 . Scale bar: $A-C, 50 \mu \mathrm{m}$ $D-F, 25 \mu \mathrm{m}$.

Figure 1. Stem cell culture and differentiation paradigm. Phase-contrast pictures of stem cells (P1D4) grown at low $(A)$, intermediate $(B)$, and high $(C)$ density. Before differentiation, all cells, as revealed by DAPI nuclear staining $(D)$, expressed nestin $(E)$ and incorporated $\operatorname{BrdU}(F)$. $G$, Schematic diagram of standard differentiation paradigm as described in Materials and Methods. $L D$, Low density; $M D$, intermediate density; $H D$, high density; $S 8$, serum- selective proliferation and/or survival, mediated the difference in cell-type composition under high- and low-density conditions. We further demonstrated that the signal to repress smooth muscle fate at high density depended on local instead of average density and could be mimicked by membrane extract. Our results provide the first demonstration of a contact-dependent mechanism in cell-fate determination of cortical stem cells.

\section{MATERIALS AND METHODS}

Dissection and stem cell culture. Cortical stem cell culture was conducted as described previously with some modifications (Johe et al., 1996). Briefly, timed-pregnant Sprague Dawley rat embryos (Charles River Laboratories, Wilmington, MA) on day 14.5 were dissected in HBSS. The morning of vaginal plug detection was designated as embryonic day 0.5. Embryos were also measured and examined for morphological hallmarks to ensure that the gestational timing was correct. After decapitation and removal of skin, skull, and meninges, forebrain was isolated. Olfactory bulb, hippocampus, striatum, thalamus, hypothalamus, and regions close to the mesencephalon were removed. Pieces of cerebral cortices were collected and mechanically triturated in $1 \mathrm{ml}$ of HBSS by passing through P1000 blue tip eight times without trypsinization. Dissociated cells were collected and resuspended in $6 \mathrm{ml}$ of serum-free medium containing: DMEM-F12, $8 \mathrm{~mm}$ glucose, glutamine, $20 \mathrm{~mm}$ sodium bicarbonate, $15 \mathrm{~mm}$ HEPES, and N2 supplement described by Bottenstein and Sato (1979) $(25 \mu \mathrm{g} / \mathrm{ml}$ insulin, $100 \mu \mathrm{g} / \mathrm{ml}$ human apotransferrin, $20 \mathrm{~nm}$ progesterone, $100 \mu \mathrm{M}$ putrescine, and $30 \mathrm{~nm}$ sodium selenite, $\mathrm{pH}$ 7.2). Live cells were counted by trypan blue exclusion assay in a hemocytometer. Two million acutely dissociated cells were plated on a $10 \mathrm{~cm}$ dish precoated with $15 \mu \mathrm{g} / \mathrm{ml}$ poly-L-ornithine (Sigma, La Jolla, CA) and $1 \mu \mathrm{g} / \mathrm{ml}$ bovine plasma fibronectin (Life Technology, Gaithersburg, MD) and cultured in N2 medium supplemented with bFGF (25

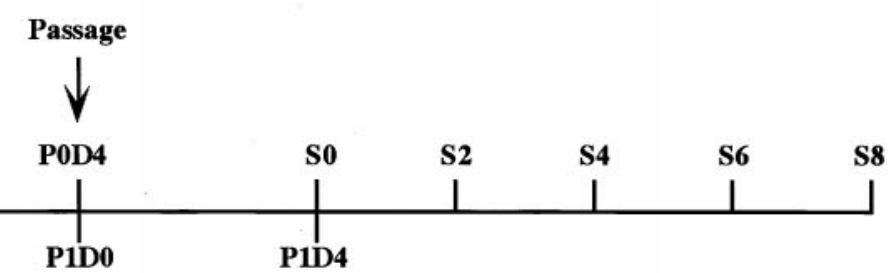

N2/bFGF
Expansion

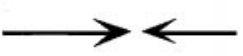

N2/10\%FBS

Differ entiation $\mathrm{ng} / \mathrm{ml}$; R \& D Systems, Minneapolis, MN) [passage 0, day 0 (P0D0)]. Cultures were maintained at $37 \mathrm{C}$ in an incubator of $95 \%$ air $-5 \% \mathrm{CO}_{2}-$ $100 \%$ humidity. bFGF was added daily, and medium was changed every 2 d. After 4 d (P0D4), cells were dissociated and replated at three different densities: high density, $1.5 \times 10^{5}$ per $10 \mathrm{~cm}$ dish $\left(1900 / \mathrm{cm}^{2}\right)$; intermediate density, $1.5 \times 10^{4}$ per $10 \mathrm{~cm}$ dish $\left(190 / \mathrm{cm}^{2}\right)$; and low density, 1500 per $10 \mathrm{~cm}$ dish $\left(19 / \mathrm{cm}^{2}\right)$. bFGF expansion was continued for an additional $4 \mathrm{~d}$ (P1D4) before induction of differentiation by $10 \%$ fetal bovine serum (FBS) and bFGF withdrawal (Fig. 1G).

Clonal analysis. Dissociated cells were plated at 400 cells per $10 \mathrm{~cm}$ dish. After $2 \mathrm{hr}$ of settling, floating cells were removed by replacing the medium with fresh medium, and well isolated single cells were marked with a $3 \mathrm{~mm}$ circle (Nikon, Tokyo, Japan) on the bottom of the plates. Only cells that were grown in a circle marked as described above were referred to as clones, others as clusters.

Immunocytochemistry. The primary antibodies and their dilution used in this study were mouse $\alpha$ - $\beta$-tubulin class III neuron-specific isotype (clone Tuj1; Babco, Richmond, CA), 1:500; rabbit $\alpha$ - glial fibrillary acidic protein (GFAP) (Dako, Carpinteria CA), 1:400; rabbit $\alpha$-nestin (R. D. G. McKay), 1:1000; mouse $\alpha$-smooth muscle actin (SMA) (Sigma, St. Louis, MO), 1:400; mouse $\alpha$-calponin (Sigma), 1:500. Secondary antibodies were Rhodamine Red or FITC-conjugated goat $\alpha$-mouse IgG (preabsorbed with rabbit and rat serum protein), 1:200; donkey $\alpha$-rabbit IgG (preabsorbed with rat and mouse serum protein), 1:200 (Jackson ImmunoResearch, West Grove, PA).

Immunolabeling was visualized by indirect fluorescence. At indicated time points, cultured cells were fixed with ice-cold $4 \%$ paraformaldehyde solution for $15 \mathrm{~min}$. After blocking with $10 \%$ normal goat serum in $1 \times$ PBS $-0.3 \%$ Triton X-100, cells were incubated with primary antibody overnight at $4^{\circ} \mathrm{C}$, followed by secondary antibody reaction for $1 \mathrm{hr}$ at room temperature. Three washes with $1 \times$ PBS for $10 \mathrm{~min}$ each were performed between primary and secondary antibody incubation and 

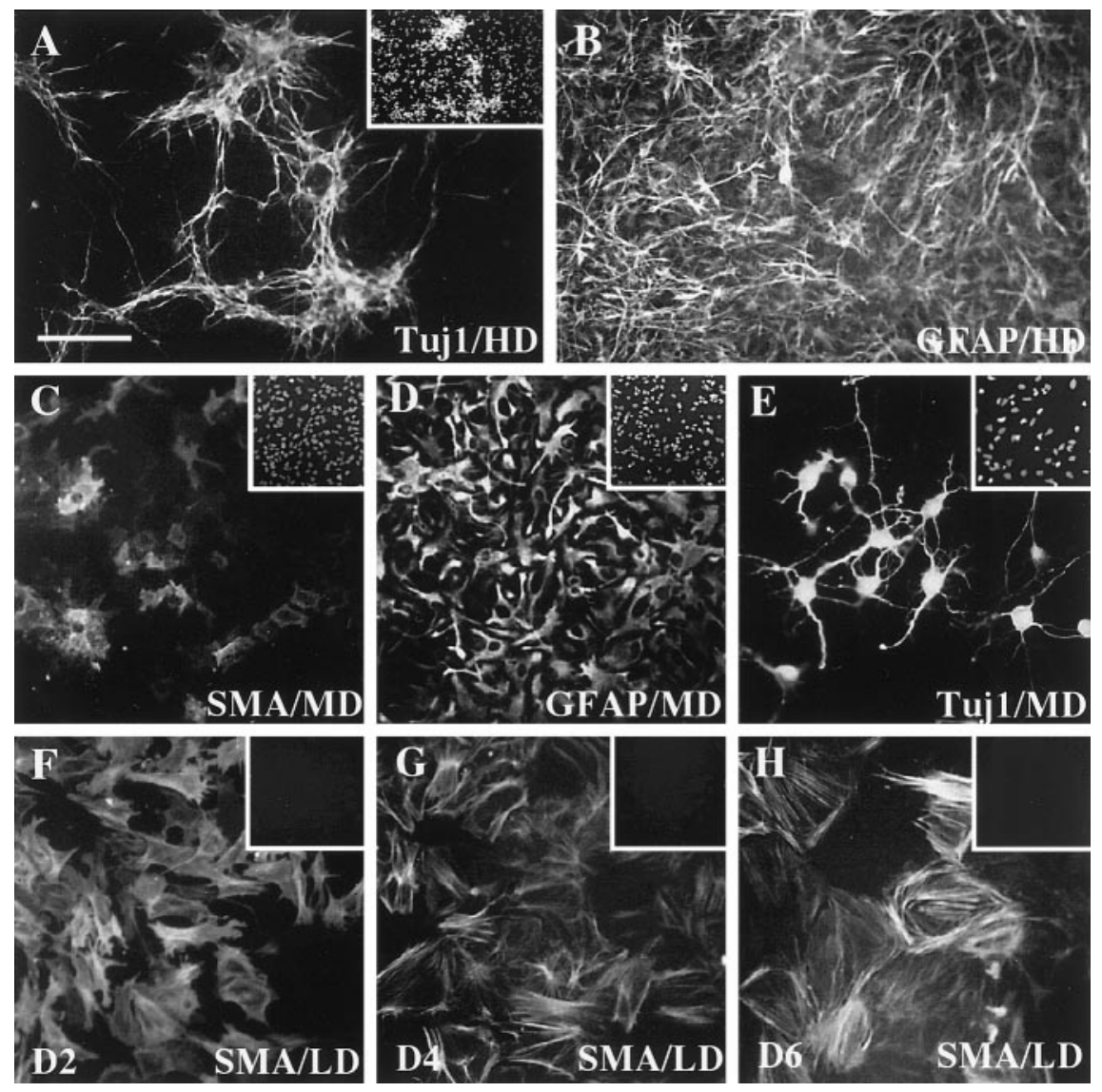

Figure 2. Cell-type composition in high-, intermediate-, and low-density cultures. After $8 \mathrm{~d}$ of differentiation in serum at high density, $15 \%$ of cells were neurons ( $A$; Tuj1), and $60-80 \%$ were astrocytes ( $B ; \alpha$-GFAP). When cells were differentiated at intermediate density for $8 \mathrm{~d}$, only a portion gave rise to smooth muscle, mostly in the margin or between clusters $(C ; \alpha$-SMA). The majority of cells became astrocytes $(D ; \alpha$-GFAP). Some cells in the center of dense clusters were labeled by Tuj1 and exhibited immature neuronal morphology $(E)$. At low density, almost all cells were $\alpha$-SMA-immunoreactive after $2 \mathrm{~d}$ of differentiation ( $F ; \alpha$-SMA). However, obvious stress fiber pattern did not appear until $4(G ; \alpha$-SMA) or $6(H ; \alpha$-SMA) d after differentiation. Insets: $A$, $C-E$, DAPI nuclear staining of the same field; $F-H$, $\alpha$-GFAP staining of the same field. $H D$, High density; $M D$, intermediate density; $L D$, low density; $D 2,2 \mathrm{~d}$ after differentiation. Scale bar: $A-D, F-H, 100 \mu \mathrm{m} ; E$, $50 \mu \mathrm{m}$. after secondary antibody reaction. For double-labeled immunofluorescence, primary antibodies raised in two different species were incubated together, followed by reaction with appropriate combination of secondary antibodies coupled to either Rhodamine Red or FITC. For some experiments, nuclear staining with 4',6 diamidino-2-phenylindole (DAPI) (1 $\mu \mathrm{g} / \mathrm{ml}$; Accurate Chemicals, Westbury, NY) was added in the secondary antibody reaction to reveal all cell nuclei in culture.

Reverse transcription-PCR. Total RNA $(1 \mu \mathrm{g})$, treated with DNaseI for $15 \mathrm{~min}$ at room temperature, was reverse-transcribed into first-strand cDNA with $300 \mathrm{ng}$ of random hexamer and M-MLV reverse transcriptase (Life Technology) in a $20 \mu \mathrm{l}$ reverse transcription (RT) reaction. Semiquantitative analysis was performed in $25 \mu \mathrm{l}$ of PCR reaction with $0.5 \mu \mathrm{l}$ of undiluted first-strand cDNA solution, $0.2 \mathrm{~mm} \mathrm{dNTP}$, and $0.4 \mathrm{~mm}$ primers. To obtain the linear range of PCR amplification, every set of PCR reaction was performed at three consecutive odd-numbered cycles determined by pilot studies. Positive control for first-strand cDNA reaction was performed with the QuantumRNA 18S internal standards (primer/Competimer, 2:8; Clontech, Cambridge, UK). Negative control for potential genomic contamination was done by leaving out the reverse transcriptase in the first-strand cDNA synthesis reaction.

The basic calponin (bCALP)-specific oligonucleotide sequences were selected from the mouse bCALP gene in regions most diverse from the rat acidic calponin. Their sequences were as follows: $5^{\prime}$ bCALP primer, GAGAGAAGGCAGGAACATCZ; 3' bCALP primer, AGTGTTCCATGCCCAGACC; 5' SM22 primer, TGTTCCAGACTGTTGACCTC; and 3' SM22 primer, GTGATACCTCAAAGCTGTCC.

Membrane preparation. The membrane preparation was based on the method of Temple and Davis (1994). Briefly, membrane was prepared from P1D4 stem cells grown under the high-density condition by osmotic lysis in $5 \mathrm{~mm}$ HEPES, $\mathrm{pH} 7.4$, and dounce homogenization. The resulting suspension was spun at $30,000 \times g$ for $45 \mathrm{~min}$. Pellets were washed with HBSS once and spun at $30,000 \times g$ for $45 \mathrm{~min}$. The resulting pellet was resuspended in HBSS, and the concentration of total membrane protein was measured using the Bradford protein assay (Bio-Rad, Hercules, CA). Membrane extract prepared as described consisted of large sheets of membrane and would attach to the culture dish after overnight incubation. For heat-inactivation, membrane extract was heated at $80^{\circ} \mathrm{C}$ for $10 \mathrm{~min}$.

\section{RESULTS}

\section{Cortical stem cells differentiate into smooth muscle at low density}

Withdrawal of the mitogenic effect of bFGF was shown to initiate cortical stem cell differentiation into neurons, astrocytes, and oligodendrocytes (Johe et al., 1996). To address the effect of cell-cell interaction on cell-fate determination, we asked how the plating density affects the outcome of cell types. Unless specified otherwise, cells were maintained in 10\% FBS after bFGF withdrawal for the purpose of increasing cell survival at high density and stabilizing neuronal differentiation. However, we made the surprising observation that, when serum was present, stem cells would differentiate predominantly into either astrocytes or smooth muscle cells depending on their density.

Serial immunocytochemical staining was performed at various time points to analyze the kinetics of cell fate at different densities. The average percentage of immunoreactive cells in 16 random high-power fields (HPFs) on a $10 \mathrm{~cm}$ dish was used for each data point, and six independent experiments were performed for every analysis. Neural stem cells were cultured at three different densities (high, intermediate, and low) as described in Materials and Methods. Before differentiation, the majority of cells formed clusters of various sizes depending on the initial plating density (Fig. $1 A-C$ ). Cells at this stage had small, round, or polygonal cell bodies with multiple short processes. All of the cells, as revealed by DAPI nuclear staining in Figure $1 D$, expressed nestin (Fig. $1 E$ ) and remained proliferative as judged by their ability to incorporate bromodeoxyuridine (BrdU) (18 hr pulse) (Fig. 1F). After differentiation, cells at high density displayed at least four 
different cell fates. Some cells in the center of dense clusters were immunoreactive to Tuj1, a monoclonal antiserum that recognizes a neuron-specific subtype of $\beta$-tubulin (Lee et al., 1990), after $2 \mathrm{~d}$ of differentiation. The maturation of neuronal morphology and Tuj1 staining required $6 \mathrm{~d}$ of differentiation. Approximately $15.1 \pm 1.1 \%(\mathrm{SD} ; n=6)$ of the total population had neuronal morphology with round, phase-bright cell body and long processes, often forming clusters on top of astrocytes, after $8 \mathrm{~d}$ of differentiation (Fig. 2A). The expression of GFAP could be detected only in a subset of cells after $2 \mathrm{~d}$. After $6 \mathrm{~d}$ of differentiation, the majority of cells displayed intensive GFAP staining and a complex fibrous morphology. The high-density culture condition and fibrous pattern of staining precluded accurate quantitation of GFAP-positive $\left(\mathrm{GFAP}^{+}\right)$cells. Sixty to $80 \%$ of cells expressed GFAP after $8 \mathrm{~d}$ of differentiation (Fig. $2 B$ ). Cells of oligodendroglial lineage were analyzed by using a panel of antibodies that recognized oligodendrocytes at different developmental stages. At $2 \mathrm{~d}$ culture, only A2B5 gave positive staining in $8.3 \pm 0.6 \%$ of cells. After $8 \mathrm{~d}$ of differentiation, immunocytochemistry revealed the following results: A2B5, $9.8 \pm 3.0 \%$; O4, $2.3 \pm 1 \%$, Rip, $1.7 \pm 1.1 \%$; and myelin basic protein, $1.0 \pm 0.3 \%$ (SD; $n=6)$. On the other hand, smooth muscle, as shown by $\alpha$-SMA immunofluorescence, constituted $<0.05 \%$ of the total population after $2 \mathrm{~d}$ of differentiation. The percentage of smooth muscle cells decreased afterward as the total population increased.

At intermediate density, SMA immunoreactivity appeared in $10-20 \%$ of cells in the peripheral region of a cluster or between clusters (Fig. 2C). The majority of cells displayed strong GFAP immunoreactivity (Fig. 2D). These $\mathrm{GFAP}^{+}$astrocytes had flat cell bodies and wide processes in contrast to the fibrous astrocytes seen at high density. Cells $(12.6 \%)$ were immunoreactive with Tuj1 (Fig. 2E). These neurons differentiated in the center of clusters, possessed simple neuritic processes, and expressed epitopes recognized by A2B5, indicating that they were young postmitotic neurons (R. Y. L. Tsai, unpublished data). On the other hand, almost all cells at low density displayed flat morphology and expressed SMA after $2 \mathrm{~d}$ of differentiation (Fig. 2F). However, the $\alpha$-SMA-labeled stress fiber pattern did not appear until 4 (Fig. 2G) and 6 (Fig. $2 H$ ) d after differentiation. In low-density culture, the $\mathrm{GFAP}^{+}$cells constituted $<1 \%$ of the total population and appeared only in the center of large-sized clusters in which the $\mathrm{GFAP}^{+}$and $\mathrm{SMA}^{+}$cells were intermixed with each other in a mosaic pattern.

Previous studies have shown that astrocytes, both in vitro and in vivo, can express SMA (Lecain et al., 1991; Buniatian et al., 1999). This raises the issue of whether the appearance of $\mathrm{SMA}^{+}$cells represents a true cell-fate switch or simply an upregulation of a single gene. To address this question, we examined the expression of two additional smooth muscle-specific proteins by immunocytochemistry and RT-PCR. The expression of bCALP, a smooth muscle-contractile protein (Owens, 1995; Miano and Olson, 1996), and SM22, a $22 \mathrm{kDa}$ protein of unknown function (Nishida et al., 1993; Solway et al., 1995; Li et al., 1996), is restricted to smooth muscle lineage in adult tissues and transiently in the early cardiac (bCALP and SM22) and skeletal (SM22) muscle during embryogenesis. $\alpha$-Calponin immunofluorescence revealed a weak staining in a small population of the cells after $2 \mathrm{~d}$ and strong immunoreactivity in $30-40 \%$ of the total population after $4 \mathrm{~d}$ (Fig. 3A, D4). After $6 \mathrm{~d}$ of differentiation, most cells were $\alpha$-calponin-positive (Fig. $3 A, D 6$ ). As shown by previous studies,

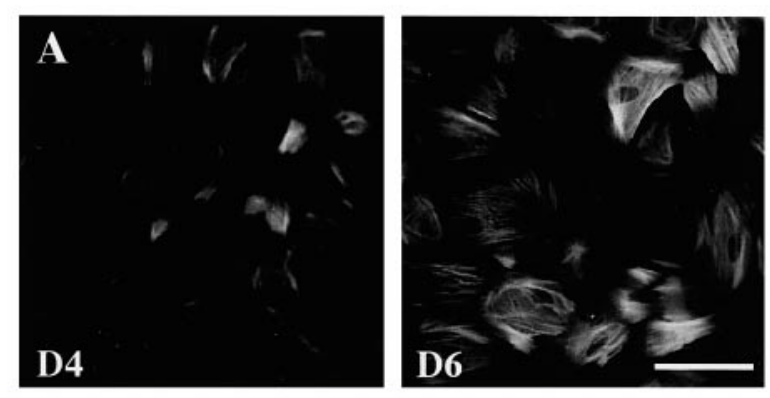

B

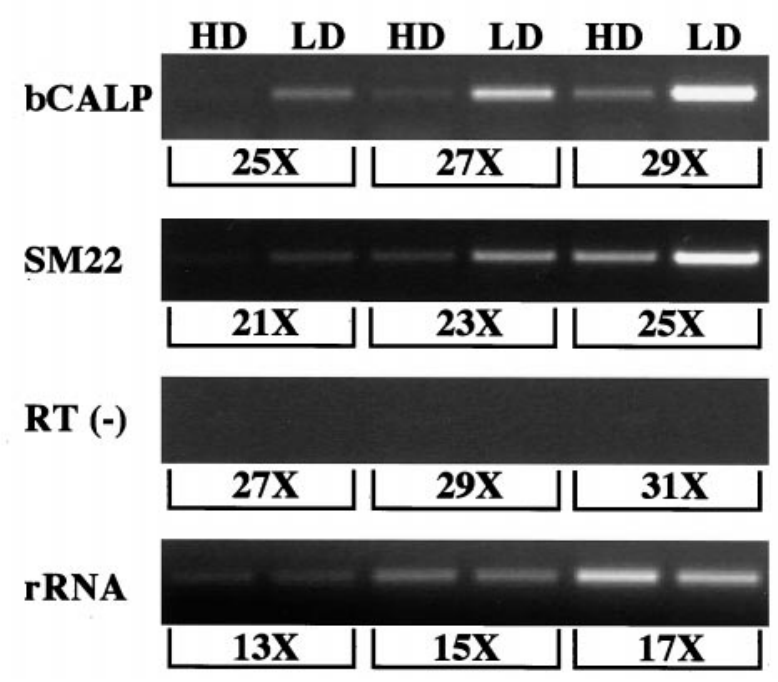

Figure 3. Expression of smooth muscle proteins at low density. Expression of several smooth muscle-specific proteins in low-density culture was examined by immunocytochemistry and RT-PCR. $A$, After $4 \mathrm{~d}$ of differentiation, $30-40 \%$ of the cells were $\alpha$-calponin-immunoreactive (D4). Almost all cells became calponin-positive after 6 d (D6). Scale bar, 100 $\mu \mathrm{m}$. $B$, Expression of bCALP and SM22 was analyzed by RT-PCR. PCR products from high- $(H D)$ and low- $(L D)$ density culture were compared side-by-side. Results from three consecutive odd-numbered PCR cycles were shown. $R T(-)$ experiment was done by omitting reverse transcriptase in the first-strand cDNA synthesis reaction to control for potential genomic contamination. rRNA $(18 \mathrm{~S})$ reaction was used to control for RNA isolation and first-strand cDNA synthesis efficiency.

cultured neurons and astrocytes can also express the acidic isoform of calponin (Represa et al., 1995; Trabelsi-Terzidis et al., 1995; Ferhat et al., 1996). Because of the lack of specific antibodies, we used RT-PCR to analyze the expression of bCALP and SM22 at high and low density. Our results showed that both bCALP and SM22 were upregulated in low-density culture when compared with high-density culture (Fig. 3B). We further cloned the PCR products and confirmed their identity by sequence analysis. Because the only cell type that was more abundant at low density than high density was smooth muscle, we concluded that, in addition to SMA, these cells also express bCALP and SM22. These results clearly demonstrated that CNS-derived smooth muscle cells expressed several differentially regulated smooth muscle markers and suggested that the myogenic-differentiation program as a whole was activated. The appearance of smooth muscle as the predominant cell fate at low density raises immediate questions of their origin and the mechanism of lineage determination. Smooth muscle cells in these cultures may be generated from a distinct stem cell that has not been identified 

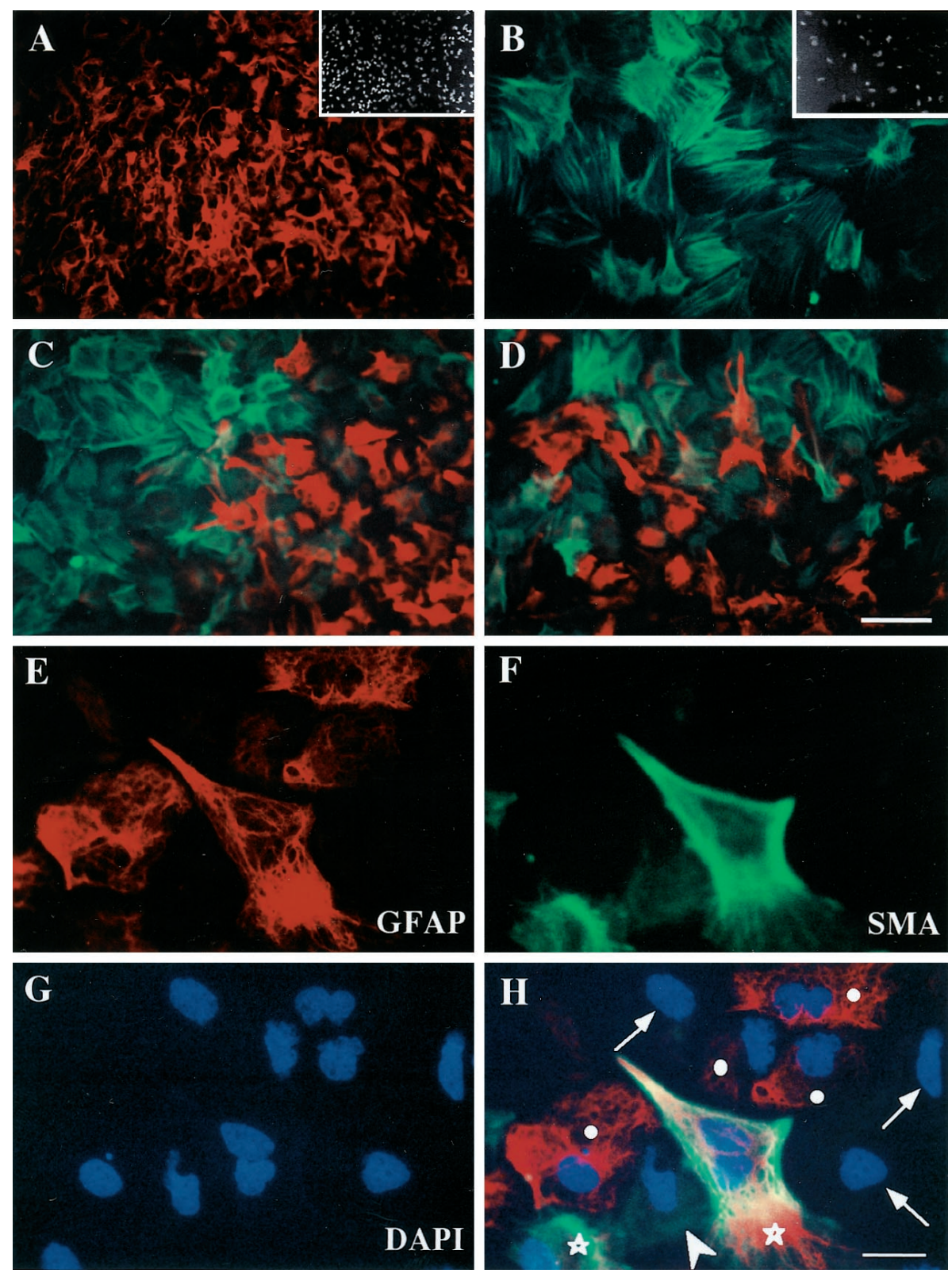

Figure 4. Smooth muscle and astrocytes were derived from the same precursors. All clones with a large clone size ( $>400$ cells per clone) gave rise to both astrocytes in the center $(A)$ and smooth muscle at the periphery $(B)$. Insets, $A-B$, DAPI staining of the same fields. At the junction, $\mathrm{GFAP}^{+}$cells intermixed with $\mathrm{SMA}^{+}$cells $(C$, $D)$. Four types of expression pattern could be identified in the transition: cells that were distinctly labeled with $\alpha$-GFAP antibody $(H$, circles $)$ or $\alpha$-SMA antibody $(H$, arrowhead $)$; cells that were both GFAP- and SMA-positive ( $H$, stars); and cells that expressed neither $(H$, thin arrows). $A-D$, Double immunofluorescence with $\alpha$-GFAP (red) and $\alpha$-SMA (green). $E, \alpha$-GFAP immunofluorescence (red). $F, \alpha$-SMA immunofluorescence (green). $G$, DAPI nuclear staining (blue). $H$, Triple staining of $\alpha$-GFAP (red), $\alpha$-SMA (green), and DAPI (blue). Scale bar: $A-D, 50 \mu \mathrm{m}$; $E-H, 25 \mu \mathrm{m}$.

\begin{tabular}{|c|c|c|c|c|c|c|c|c|c|c|c|c|}
\hline Cell no./clone & 0 & 1 & 2 & 3 & 4 & 5 & 6 & 7 & 8 & 9 & 10 & $>10$ \\
\hline No. of clone & 108 & 122 & 141 & 125 & 97 & 60 & 33 & 27 & 16 & 7 & 4 & 3 \\
\hline$\%$ Clone/total & 14.5 & 16.4 & 19.0 & 16.8 & 13.1 & 8.1 & 4.5 & 3.6 & 2.2 & 0.9 & 0.5 & 0.4 \\
\hline
\end{tabular}

previously. Alternatively, smooth muscle and astrocytes might be derived from a common precursor with density acting instructively on cell-fate determination or selectively on proliferation and/or survival.

\section{Smooth muscle and astrocytes are derived from the same lineage}

To address whether smooth muscle is derived from a separate lineage, we performed the following experiments. P1D0 stem cells as described in Figure $1 G$ were plated at clonal density (400 per $10 \mathrm{~cm} \mathrm{dish),} \mathrm{and} \mathrm{well} \mathrm{isolated} \mathrm{single} \mathrm{cells} \mathrm{were} \mathrm{marked} \mathrm{after}$
$2 \mathrm{hr}$ of settling. Clones were grown for $6 \mathrm{~d}$ (P1D6) in bFGF before induction of differentiation. Twenty percent of the marked clones grew to a large clone size ( $>400$ cells per clone). Cell fates were assessed by the expression of GFAP, SMA, and $\beta$-tubulin for astrocytes, smooth muscle, and neurons, respectively. As shown in Figure 4, both astrocytes and smooth muscle were found in the same clone. Within every clone, $\mathrm{GFAP}^{+}$cells were invariably present in the central dense region (Fig. 4A), whereas $\mathrm{SMA}^{+}$cells were distributed peripherally and away from one another (Fig. $4 B$ ). In the junctional region, GFAP ${ }^{+}$ 

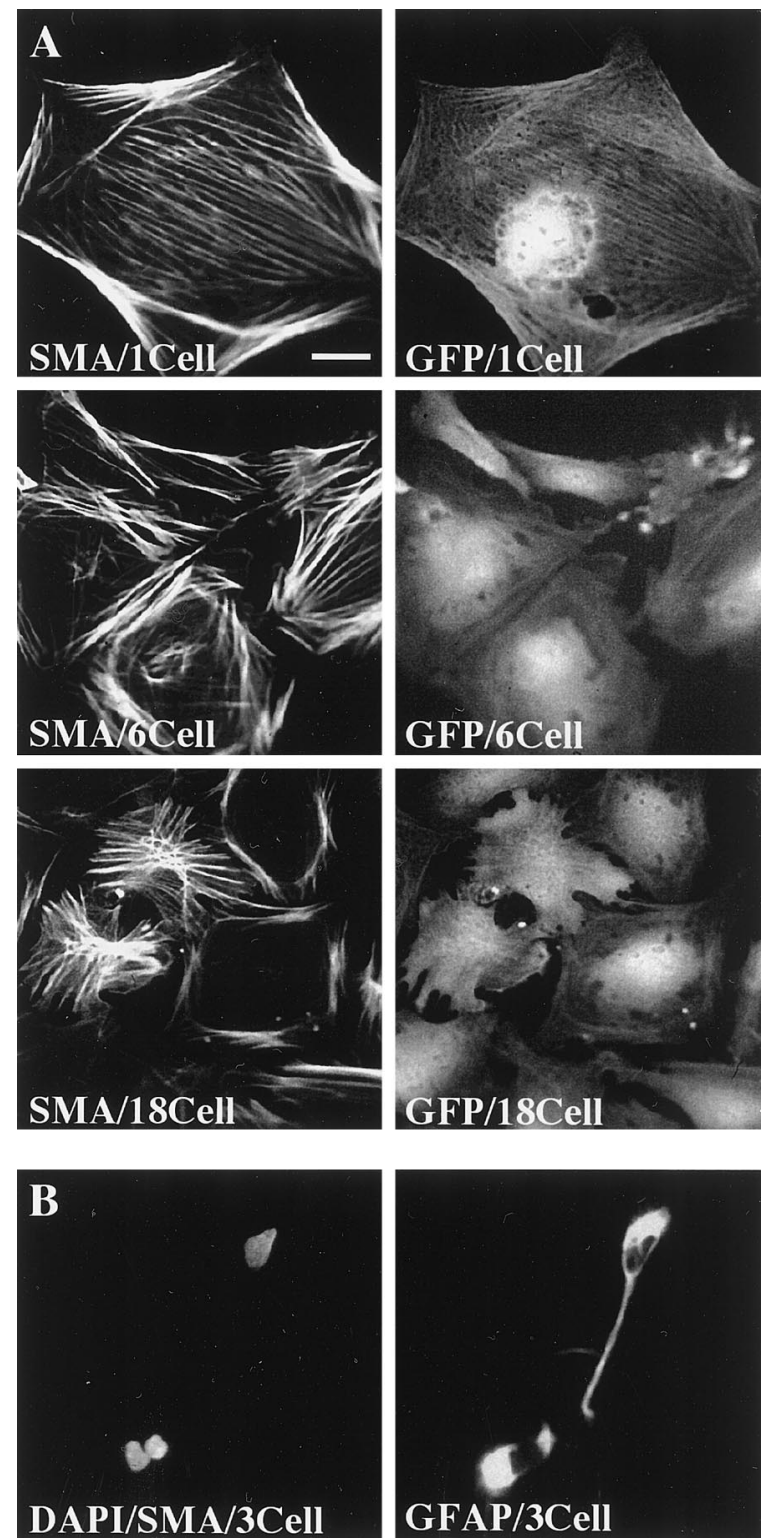

Figure 5. Cells expanded at high density differentiated into smooth muscle at low density. Stem cells grown at high density (P1D4) were labeled with green fluorescence protein (GFP)-expressing retrovirus and replated at clonal density before differentiation. $A$, Under the regular differentiation paradigm (10\% FBS), all surviving cells expressed SMA and smooth muscle morphology. $\alpha$-SMA (left panel) and $\alpha$-GFP (right panel ) immunofluorescence image of 1-cell, 6-cell, and 18-cell clones. $B$, On the other hand, when cells in a parallel preparation were exposed to CNTF $(20 \mathrm{ng} / \mathrm{ml})$ as the differentiating signal, they all became GFAPpositive and SMA-negative. $\alpha$-SMA-DAPI (left panel) and $\alpha$-GFAP (right panel) immunofluorescence image. Scale bar: $A, B, 25 \mu \mathrm{m}$.

cells were intermixed with $\mathrm{SMA}^{+}$cells in a mosaic pattern (Fig. 4C,D). Interestingly, we found that some cells expressed both antigens strongly (Fig. 4H, stars) and some expressed neither (Fig. $4 H$, thin arrows). The relative ratio of GFAP to SMA cells within individual clones depends on the clone size, with $>80 \%$ of the cells expressing GFAP marker in large-sized clones to almost all smooth muscle in clones $<100$ cells. These data indicate that astrocytes and smooth muscle were derived from a common precursor during the period of dissection and P0 expansion.
Table 2. Intraclonal analysis of cell fate and survival

\begin{tabular}{lcl} 
& No. of clone & \% Clone/total \\
\hline All SM no cell death & 172 & 60.4 \\
All SM before cell death & 50 & 17.5 \\
Some cell death before all SM & 30 & 10.5 \\
All cells die before SM & & \\
$\quad$ 1 Cell stage & 22 & 7.7 \\
2 Cells stage & 10 & 3.5 \\
Oligodendrocyte & 1 & 0.4 \\
\hline
\end{tabular}

\section{Stem cells grown at high density retain the same developmental potential as cells grown at low density}

Cells expanded at high density may undergo cell-fate restriction and possess different developmental potential from cells grown at low density. To examine this possibility, P1D4 cells grown at high density were replated at clonal density. Single cells were marked $2 \mathrm{hr}$ after plating and induced to differentiate by $10 \%$ FBS. The cell number and expression of GFAP and SMA of every clone was analyzed 3 d later. Quantitative analysis of 743 clones from four separate experiments showed that the number of cells within a clone ranged from 0 to 18 cells. Most clones contained one to three cells (52.2\%) (Table 1). All of the cells that survived after $3 \mathrm{~d}$ of differentiation at low density showed smooth muscle morphology and expressed SMA (Fig. 5A). Of all clones analyzed, only $14.5 \%$ of them died and therefore failed to give rise to smooth muscle fates. If these cells that died at low density represented a nonsmooth muscle lineage, they would have to divide 13.5 times in $2 \mathrm{~d}$ to make up for the 2000:1 nonsmooth muscle to smooth muscle ratio at high density.

One potential artifact introduced by the replating and clonal analysis procedure is selective dissociation, adherence, and/or survival of certain cell types. To address this possibility, we conducted a parallel experiment as described in Figure $5 A$ with the exception of differentiating condition. Instead of $10 \%$ FBS, CNTF (20 ng/ml), which was shown to induce astrocytic differentiation in $>97 \%$ of cultured stem cells (Johe et al., 1996), was used as the differentiating signal. We showed that CNTF could block the differentiation of the exact same cells to a smooth muscle fate and promote astrocytic differentiation at low density (Fig. 5B). This result demonstrated that passaged cells still possessed both developmental potentials to become astrocytes and smooth muscle and ruled out the possibility of differential selection of smooth muscle precursors during the replating procedure. In addition, the viability of dissociated cells in single-cell suspension was consistently $95 \%$, and the efficiency of adherence was $87 \%$. The undetached cells after dissociation behaved in the same way as the dissociated cells. Therefore, it was unlikely that we were just observing a subpopulation of cells that were selected by the clonal analysis procedure. These results exclude the possibility that cells are committed to a different lineage during bFGF expansion at high density.

\section{Density acts instructively on cell-fate determination}

The previous results demonstrate that smooth muscle and astrocytes were derived from precursors with the same developmental potential before differentiation. Two possible mechanisms remain for the density effect on cell types. Density can either affect the proliferation and/or survival of selective cell types without influencing the fate choice or act instructively on lineage determina- 

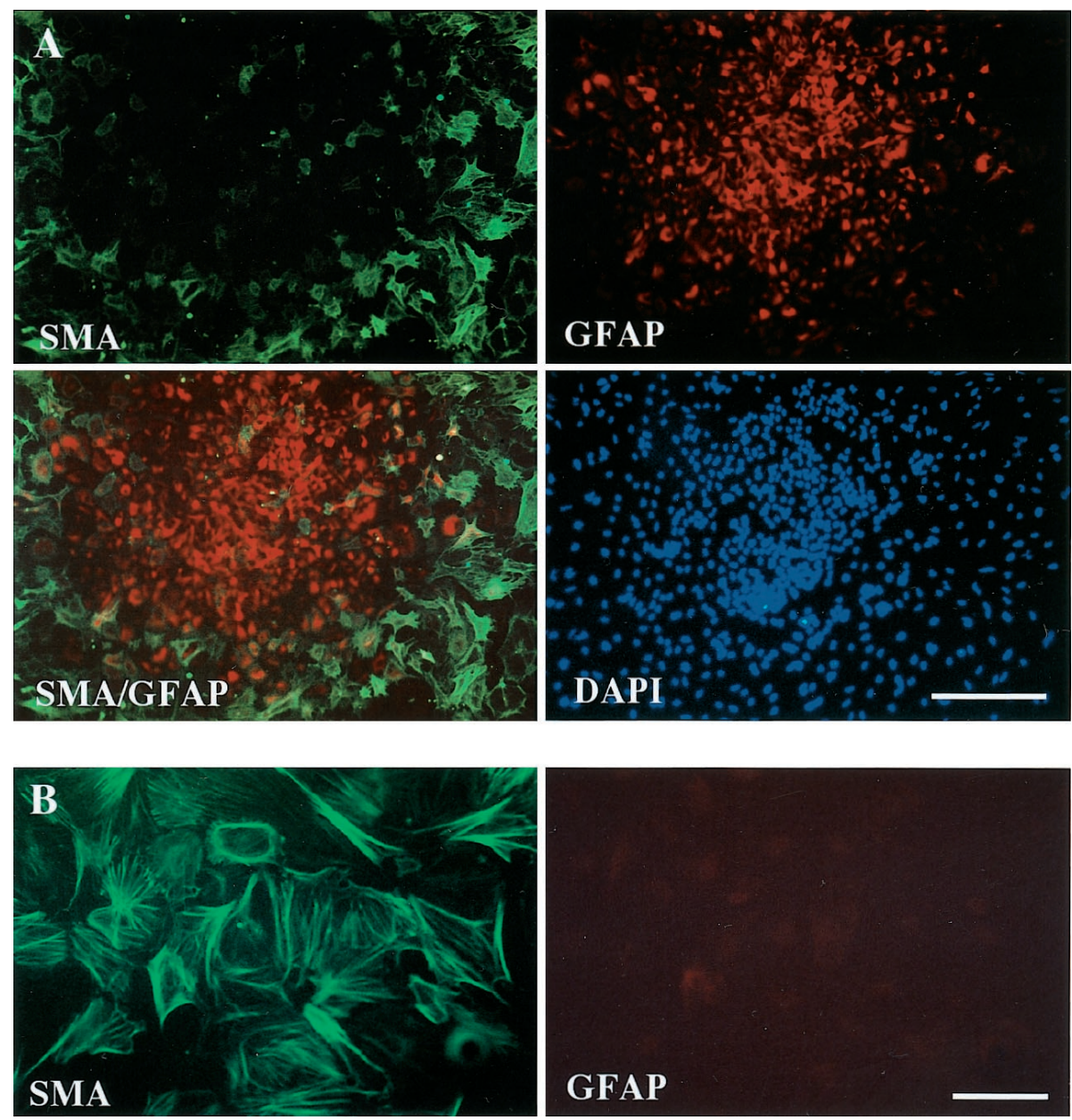

Figure 6. Effect of local versus average density on cell-fate determination. $A$, Cells grown at high local density but low average density gave rise to both astrocytes and smooth muscle. $B$, Cultures with evenly dispersed cells all differentiated into smooth muscle despite higher total cell count per plate. $\alpha$-SMA immunofluorescence (green); $\alpha$-GFAP immunofluorescence (red); DAPI nuclear staining (blue). Scale bar: $A$, $300 \mu \mathrm{m} ; B, 100 \mu \mathrm{m}$. tion. To distinguish between these two possibilities, single cells were marked and grown in serum-containing medium. The development of identified clones was followed sequentially after $8 \mathrm{hr}$ and thereafter every $24 \mathrm{hr}$ for cell survival and morphology. After $5 \mathrm{~d}$, the cellular identity was confirmed by immunocytochemistry (Table 2). Of 285 clones examined, $60.4 \%$ of the clones gave rise to only smooth muscle without cell death, and $17.5 \%$ of the clones became all smooth muscle before revealing any cell death. Only $10.5 \%$ of the clones exhibited intraclonal cell death before becoming smooth muscle. If neurons and glia were derived from these clones that exhibited intraclonal cell death before commitment to smooth muscle lineage, they would have to divide 12.8 times in $2 \mathrm{~d}$ to account for the difference seen at high and low density (see Discussion). Therefore, it is unlikely that densitymediated cell-type switch could be attributed to the selective mechanism. Based on the data presented (Figs. 4, 5; Tables 1, 2), we conclude that the models of two lineages, cell-fate restriction during bFGF expansion at high density, or selective proliferation and/or survival could not account for the cell-type composition seen at different densities. Therefore, cell density must act directly on cell-fate determination.

\section{Cell fates are affected by local density instead of average density}

The density effect on smooth muscle cell fate could be caused by local signals or by global signals, such as tropic factors and medium deprivation at high density. To address the effect of local versus global density, we compared two culture conditions with similar average density but distinct intercellular distance: one with higher intraclonal density but fewer clones and the other with evenly dispersed cells. For culture with high intraclonal density, P1 cells were plated clonally (200 cells per $10 \mathrm{~cm}$ dish) and grown for $6 \mathrm{~d}$ in bFGF. Approximately 10-20 clusters on each plate achieved large clone size and high local density in the center. The total cell number on these plates was estimated to be $1.2 \times 10^{4}$ per $10 \mathrm{~cm}$ plate. To obtain cultures with evenly dispersed cells and high average density, P1D4 cells were replated at high density and induced to differentiate by mitogen withdrawal $1 \mathrm{~d}$ later. The total cell count in this condition was $1 \times 10^{5}$ per 10 $\mathrm{cm}$ dish. As shown in Figure 6, cells grown at high intraclonal density but low average density gave rise to both astrocytes and smooth muscle $(A)$, whereas cells grown at low local density all became smooth muscle despite their higher average density $(B)$. These findings demonstrated that the density effect on fate choice occurred in the local microenvironment and excluded the possibilities of long-ranged diffusible factors or medium deprivation as the cause.

\section{The effect of density on cell fate can be mimicked by stem cell membrane extract}

The effect of local signals could be mediated by cell-cell contact or short-ranged and/or short-lived secreted molecules. To test the hypothesis that smooth muscle fate could be inhibited at low density by membrane prepared from P1D4 cortical stem cell, 



Figure 7. Membrane-mediated fate switch of smooth muscle cells to astrocytes. Stem cells were cultured with homotypic surface membrane before induction of differentiation. Isolated astrocytes could be seen in low-density culture with $25 \mu \mathrm{g} / \mathrm{ml}$ membrane extract $(A-C)$, whereas in the control group, most cells were smooth muscle $(D-F)$. $A, D$, DAPI staining. $B, E, \alpha$-GFAP immunofluorescence. $C, F, \alpha$-SMA immunofluorescence. Scale bar, $25 \mu \mathrm{m}$. $G$, Quantitative analysis of SMA to GFAP ratio in cultures with no membrane added (Cntrl) $(10.0 \pm 2.2, \mathrm{SD} ; n=2), 25 \mu \mathrm{g} / \mathrm{ml}$ heat-inactivated membrane (Heat $T x)(7.5 \pm 0.3, \mathrm{SD} ; n=$ 2 ), and $25 \mu \mathrm{g} / \mathrm{ml}$ native membrane extract (Membrane) $(2.7 \pm 0.9, \mathrm{SD} ; n=2)$. Error bars represent SD.

dissociated stem cells were mixed with membrane extract for $2 \mathrm{hr}$ in suspension to allow for binding and plated on $6 \mathrm{~cm}$ dishes $\left(1266 / \mathrm{cm}^{2}\right)$. Twenty-four hours after plating, cells were induced to differentiate by serum. After $6 \mathrm{~d}$ of differentiation, cell types were assessed by the expression of GFAP and SMA in 80 HPFs per $6 \mathrm{~cm}$ dish. Two independent experiments were performed for each analysis. In the presence of membrane extract, isolated GFAP-expressing cells were seen at low density (Fig. 7B) in contrast to the usual smooth muscle fate without membrane extract (Fig. $7 F$ ). Our results revealed a fourfold decrease in the SMA to GFAP ratio $(2.7 \pm 0.9, \mathrm{SD} ; n=2)$ with $25 \mu \mathrm{g} / \mathrm{ml}$ of membrane extract, and a 1.5 -fold decrease $(7.5 \pm 0.3, \mathrm{SD} ; n=2)$ with $25 \mu \mathrm{g} / \mathrm{ml}$ of heat-inactivated membrane extract over control group $(10.0 \pm 2.2, \mathrm{SD} ; n=2)$ (Fig. $7 G)$. Although our findings suggest that the effect of local density is mediated by cell-cell contact, we cannot exclude the possibility that short-ranged secreted signals are also working in parallel.

\section{DISCUSSION}

We have used a culture system of multipotent stem cells to examine the effect of cell contact on lineage determination. This in vitro system offers the advantage of revealing the full developmental potential of stem cells without the restraint imposed by the in vivo

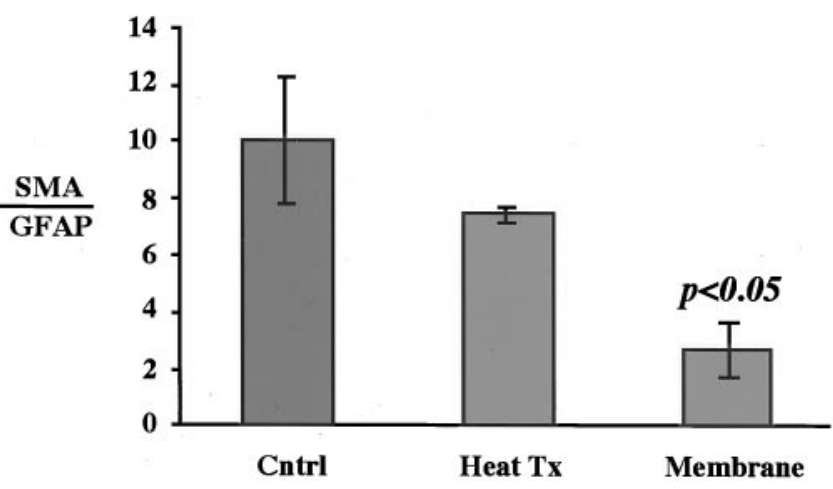

environment. In this study, we observed the development of astrocytes or smooth muscle from cortical stem cells in a densitydependent manner. In contrast to previous work showing the effect of soluble factors on cell fate, changing the cell density as a variable directly influences the number of cells in different culture conditions and makes quantitative analysis of cell fate more complex.

\section{Smooth muscle as a distinct cell fate of cortical stem cells}

Previous studies reported the expression of SMA in astrocytes both in vivo and in vitro (Lecain et al., 1991; Buniatian et al., 1999) and in other nonmuscle cell types (Schmitt-Graff et al., 1990; Jahoda et al., 1991; Peled et al., 1999). We have shown that the density effect on astrocyte-to-smooth muscle conversion seen here is more than a single-gene regulation. The expression of SMA is invariably accompanied by a downregulation of GFAP expression, as well as morphological changes. Most importantly, we demonstrate that, under low-density condition, distinct groups of differentially regulated smooth muscle-specific proteins (i.e., SMA, bCALP, and SM22) are all being upregulated. Together, these results strongly indicate that the myogenic-differentiation program as a whole is activated. 

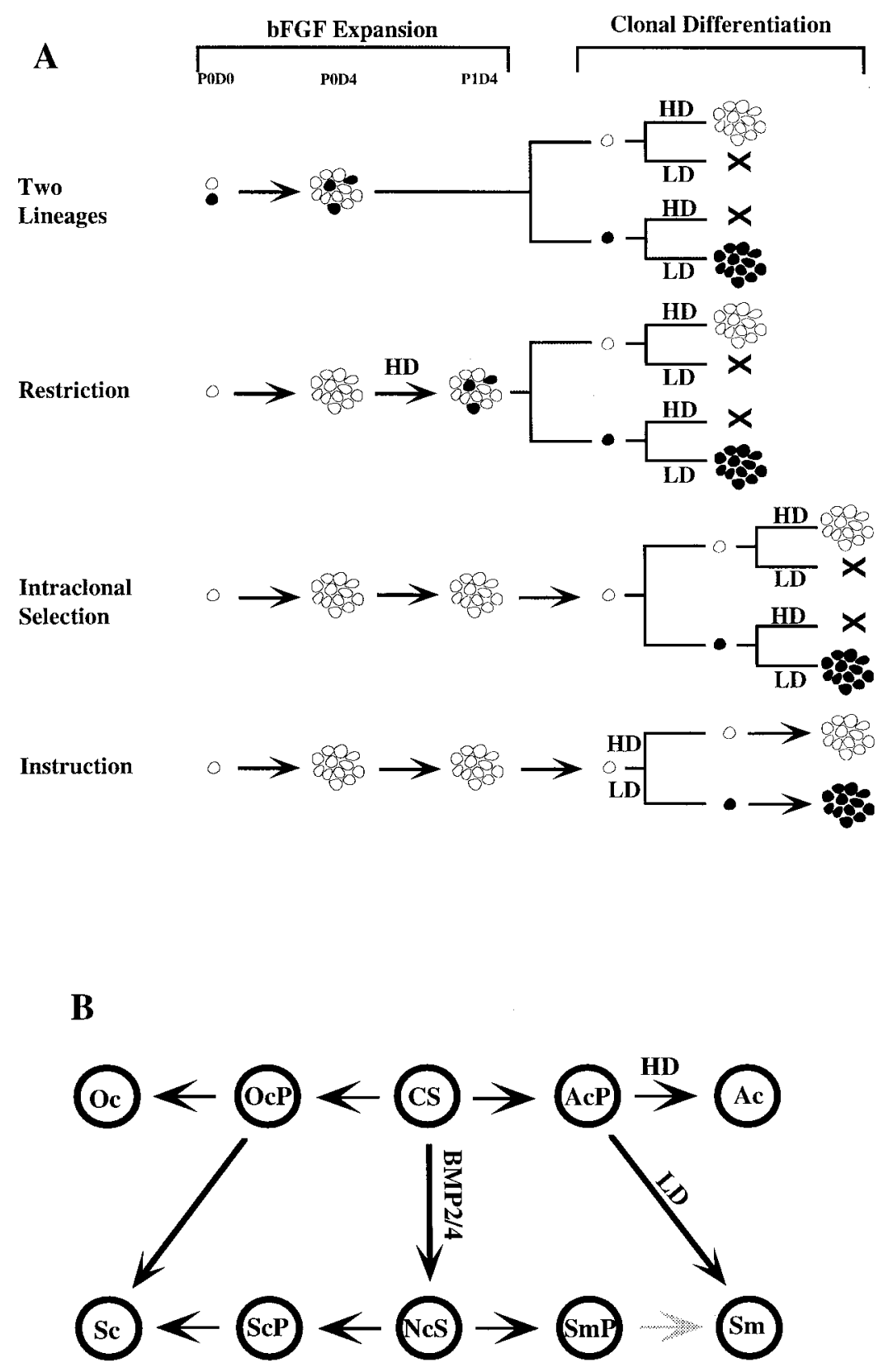

Figure 8 . Models of density-mediated fate choice by cortical stem cells. $A$, Schematic diagram of four regulatory mechanisms of the density effect on cell types. $B$, A model of CNS-to-PNS cell-fate switch during cellular differentiation. $C S$, Cortical stem cell; $N c S$, neural crest stem cell; $A c P$, astrocytic precursor; $A c$, astrocyte; $O c P$, PSA-NCAM ${ }^{+}$oligodendrocyte precursor; $O c$, oligodendrocyte; $S m P$, smooth muscle precursor; $S m$, smooth muscle; $S c P$, Schwann cell precursor; $S c$, Schwann cell; $H D$, high density; $L D$, low density.

\section{Instructive versus selective effects of density on cell-type composition}

To explain the cell-type composition at high and low density, four possible regulatory mechanisms are proposed (Fig. $8 A$ ). In the first two models, smooth muscle and astrocytes are derived from different precursors present during dissection and P0 expansion (two lineages) or during bFGF expansion at high density (restriction). After differentiation, density could influence the survival and/or proliferation of specific cell types. In the other two scenarios, smooth muscle and astrocytes are derived from the same precursor before differentiation. Here, density might act on a common precursor to influence the proliferation and/or survival of specific lineages within a clone (intraclonal selection) or instructively on the fate choice of multipotent stem cells (instruction).

In the first (two-lineage) model, smooth muscle might come from precursors of meningeal or neural crest origin. By clonal analysis of P0D4 stem cells, we demonstrated that the same precursors could give rise to both smooth muscle and astrocytes as long as they grew to a larger clone size ( $>400$ cells per clone). Invariably, astrocytes were always present in the center with smooth muscle in the periphery (Fig. 4). In the second model, precursors expanded in bFGF at high density might undergo cell-fate restriction, and density might act selectively on the proliferation and/or survival of certain cell types during differentiation. In the clonal analysis of P1D4 stem cells expanded at high density, $85.5 \%$ of the clones survived at low density, and they all gave rise to smooth muscle. If interclonal selection were to account for the different profiles seen at high and low density, some of the remaining clones would have to give rise to glial progeny and divide at an unprecedented rate that would make up the nonsmooth muscle to smooth muscle ratio seen at high density (>2000:1) in $2 \mathrm{~d}$. Compared with the doubling time of CNS stem cells in vivo (10-12 hr) (Takahashi et al., 1995; Cai et al., 1997) and in vitro (24 hr) (Johe et al., 1996), this rate seemed implau- 
sible for most cells, particularly in the absence of mitogen. One caveat in this calculation was the survival rate of the $85.5 \%$ smooth muscle clones. If these clones showed substantial cell death at high density, the required doubling time for those $14.5 \%$ clones would be longer than we estimated. To address this possibility, we calculated the percentage of cell death at high density after 1 and $2 \mathrm{~d}$ of differentiation. We found that only $1.2 \%$ of cells died after $1 \mathrm{~d}$ and $3.6 \%$ after $2 \mathrm{~d}$. Therefore, it was unlikely that these $85.5 \%$ smooth muscle clones would suffer enough cell death to offset this analysis.

These results strongly favor a common precursor for astrocytic and smooth muscle fates. These multipotent cells may choose their fates stochastically, and cell density may act selectively within individual clones to promote the survival and/or proliferation of neurons and glia at high density and that of smooth muscle at low density. If this intraclonal selection mechanism were to work, nonsmooth muscle clones would still need to divide 12.8 times in $2 \mathrm{~d}$ [amplification ratio: $2000 \times(78 \% / 22 \%)=7000$ ]. This calculated mitotic rate is still too fast for progenitors in vivo or in vitro, especially when they are undergoing differentiation. Together, we conclude that density affects cell lineage by an instructive mechanism.

\section{Developmental stage at which the fate switch occurs}

Previous work by Mujtaba et al. (1998) and Hazel et al. (1997) suggested that CNS stem cells could switch fate to neural crest stem cells in the presence of BMP2/4. In our study, the presence of some cells that are immunoreactive to both SMA and GFAP in the junctional region (Fig. $4 H$, stars) suggests that astrocytes and smooth muscle can transdifferentiate to each other at a later developmental stage and may represent part of a continuum of phenotypes. Consistent with this notion, no transient population

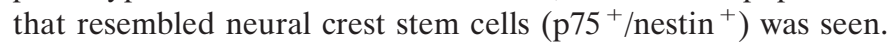
In the high intraclonal density culture paradigm as described in Figures 4 and 6, all cells were p75-negative at 1, 2, and $3 \mathrm{~d}$ after differentiation (Tsai, unpublished data). We hypothesize that the differentiation of specific phenotypes requires continuous regulatory signals from the external environment. At different developmental stages, cells of CNS origin can exhibit remarkable plasticity and the ability to transdifferentiate into PNS lineage (Fig. 8B). When the switch takes place at the precursor level, cells possess the potential to generate all lineages of neural crest origin. On the other hand, cells that have undergone some degree of fate restriction can only transdifferentiate into cells that possess similar molecular or cellular machinery. In support of this model, previous work by Keirstead et al. (1999) has shown that CNS progenitors could generate both oligodendrocytes and Schwann cells. In their study, this cell-type switch occurred after precursors became polysialyated neural cell adhesion molecule (PSANCAM)-positive. Our results suggest that smooth muscle and astrocytic fates can be directly acquired by a common CNS progenitor. However, whether these smooth muscle cells are identical to the smooth muscle in vivo or those derived from neural crest stem cells remains unknown (Fig. 8, light arrow).

\section{Possible signaling mechanisms}

The pattern of smooth muscle repression, particularly in the transitional region, is reminiscent of the local signaling mechanism of Drosophila Notch protein (Artavanis-Tsakonas et al., 1995). In Drosophila and Caenorhabditis elegans, Notch mediates the specification of numerous cell fates by the mechanism of lateral inhibition, a process that involves interaction between signaling cells and neighboring cells. A balance between the activation of Notch, an inhibitory signal for neurogenesis, and proneural genes ultimately leads to different fates among a group of initially equivalent cells. In mammalian cells, an activated Notch can suppress neurogenesis and myogenesis without affecting gliogenesis (Nye et al., 1994). Although mammalian Notch proteins (Notch1 and Notch2) and their ligands (Dll, jagged and jagged2) can be detected in cortical stem cells by RT-PCR (Tsai, unpublished data), we have yet to demonstrate successfully the presence of Notch proteins on the surface membrane by immunocytochemistry. To prove that endogenous Notch proteins are responsible for density-mediated cell fate change, one needs to demonstrate that the C-terminal portion of Notch can be translocated into nucleus in a density-dependent way (Kopan and Cagan, 1997) and that repression of smooth muscle fate at high density can be reversed by antagonists to the Notch signaling pathway (Verdi et al., 1996; Zhong et al., 1996; Kato et al., 1997; Zhong et al., 1997; Matsuno et al., 1998). Another membrane receptor implicated in cell-fate determination is the Wnt/Frizzled protein family. LaBonne and Bronner-Fraser (1998) have shown that Wnt signaling is required during neural crest induction. However, in their report, activation of Wnt pathway led to the induction, instead of repression, of neural crest derivatives, such as smooth muscle (LaBonne and Bronner-Fraser, 1998). A recent study has shown that functional expression of TGF- $\beta$ receptor and nuclear localization of Smad2 was decreased in fibroblasts growing at high density (Petridou et al., 2000). It would be interesting to see whether such a regulatory mechanism of receptor and Smad proteins is the target of this membrane-bound signal.

\section{Conclusion}

Our results indicate that homotypic interaction between stem cells represses smooth muscle fate and promotes astrocytic lineage by an instructive mechanism. We cannot distinguish yet whether the primary effect of cell contact is to repress smooth muscle generation, promote gliogenesis, or a combination of both. Nevertheless, the data present a clear demonstration of a cell-fate determination mechanism mediated by homotypic cell contact in cortical stem cells. The significance of the roles of membrane-mediated fate switch between smooth muscle and astrocytes in vivo is unknown. If CNS stem cells can adopt the smooth muscle fate in vivo, this process may be involved in the formation of blood-brain interface that is made up by astrocytes, smooth muscle, and endothelial cells.

\section{REFERENCES}

Artavanis-Tsakonas S, Matsuno K, Fortini ME (1995) Notch signaling. Science 268:225-232.

Barakat I, Sensenbrenner M, Vincendon G (1982) The importance of cell contact for the proliferation of neuroblasts in culture and its stimulation by meningeal extract. Neurochem Res 7:287-300.

Bottenstein JE, Sato GH (1979) Growth of a rat neuroblastoma cell line in serum-free supplemented medium. Proc Natl Acad Sci USA 76:514-517.

Buniatian GH, Gebhardt R, Mecke D, Traub P, Wiesinger H (1999) Common myofibroblastic features of newborn rat astrocytes and cirrhotic rat liver stellate cells in early cultures and in vivo. Neurochem Int 35:317-327.

Cai L, Hayes NL, Nowakowski RS (1997) Local homogeneity of cell cycle length in developing mouse cortex. J Neurosci 17:2079-2087.

Ferhat L, Charton G, Represa A, Ben-Ari Y, der Terrossian E, Khrestchatisky M (1996) Acidic calponin cloned from neural cells is differentially expressed during rat brain development. Eur J Neurosci 8:1501-1509. 
Gage FH, Ray J, Fisher LJ (1995) Isolation, characterization, and use of stem cells from the CNS. Annu Rev Neurosci 18:159-192.

Galileo DS, Gray GE, Owens GC, Majors J, Sanes JR (1990) Neurons and glia arise from a common progenitor in chicken optic tectum: demonstration with two retroviruses and cell type-specific antibodies. Proc Natl Acad Sci USA 87:458-462.

Gao WO, Heintz N, Hatten ME (1991) Cerebellar granule cell neurogenesis is regulated by cell-cell interactions in vitro. Neuron 6:705-715.

Ghosh A, Greenberg ME (1995) Distinct roles for bFGF and NT-3 in the regulation of cortical neurogenesis. Neuron 15:89-103.

Hatten ME (1985) Neuronal regulation of astroglial morphology and proliferation in vitro. J Cell Biol 100:384-396.

Hatten ME (1987) Neuronal inhibition of astroglial cell proliferation is membrane mediated. J Cell Biol 104:1353-1360.

Hazel T, Panchision DM, Warriner P, McKay RDG (1997) Regional plasticity of multipotential precursors from the developing CNS. Meeting for the Society for Neuroscience, October, 1997.

Jahoda CA, Reynolds AJ, Chaponnier C, Forester JC, Gabbiani G (1991) Smooth muscle alpha-actin is a marker for hair follicle dermis in vivo and in vitro. J Cell Sci 99:627-636.

Johe KK, Hazel TG, Muller T, Dugich-Djordjevic MM, McKay RD (1996) Single factors direct the differentiation of stem cells from the fetal and adult central nervous system. Genes Dev 10:3129-3140.

Kato H, Taniguchi Y, Kurooka H, Minoguchi S, Sakai T, NomuraOkazaki S, Tamura K, Honjo T (1997) Involvement of RBP-J in biological functions of mouse Notch1 and its derivatives. Development 124:4133-4141.

Keirstead HS, Ben-Hur T, Rogister B, O'Leary MT, Dubois-Dalcq M, Blakemore WF (1999) Polysialylated neural cell adhesion moleculepositive CNS precursors generate both oligodendrocytes and Schwann cells to remyelinate the CNS after transplantation. J Neurosci 19:7529-7536.

Kilpatrick TJ, Bartlett PF (1993) Cloning and growth of multipotential neural precursors: requirements for proliferation and differentiation. Neuron 10:255-265.

Koblar SA, Turnley AM, Classon BJ, Reid KL, Ware CB, Cheema SS, Murphy M, Bartlett PF (1998) Neural precursor differentiation into astrocytes requires signaling through the leukemia inhibitory factor receptor. Proc Natl Acad Sci USA 95:3178-3181.

Kopan R, Cagan R (1997) Notch on the cutting edge. Trends Genet 13:465-467.

LaBonne C, Bronner-Fraser M (1998) Neural crest induction in Xenopus: evidence for a two-signal model. Development 125:2403-2414.

Lecain E, Alliot F, Laine MC, Calas B, Pessac B (1991) Alpha isoform of smooth muscle actin is expressed in astrocytes in vitro and in vivo. J Neurosci Res 28:601-606.

Lee MK, Tuttle JB, Rebhun LI, Cleveland DW, Frankfurter A (1990) The expression and posttranslational modification of a neuron-specific beta-tubulin isotype during chick embryogenesis. Cell Motil Cytoskeleton 17:118-132.

Lendahl U, Zimmerman LB, McKay RD (1990) CNS stem cells express a new class of intermediate filament protein. Cell 60:585-595.

Li L, Miano JM, Cserjesi P, Olson EN (1996) SM22 alpha, a marker of adult smooth muscle, is expressed in multiple myogenic lineages during embryogenesis. Circ Res 78:188-195.

Lillien LE, Raff MC (1990) Differentiation signals in the CNS: type-2 astrocyte development in vitro as a model system. Neuron 5:111-119.

Luskin MB, Pearlman AL, Sanes JR (1988) Cell lineage in the cerebral cortex of the mouse studied in vivo and in vitro with a recombinant retrovirus. Neuron 1:635-647.

Matsuno K, Eastman D, Mitsiades T, Quinn AM, Carcanciu ML, Ordentlich P, Kadesch T, Artavanis-Tsakonas S (1998) Human deltex is a conserved regulator of Notch signalling. Nat Genet 19:74-78.

McKay R (1997) Stem cells in the central nervous system. Science 276:66-71.

McMorris FA, Dubois-Dalcq M (1988) Insulin-like growth factor I promotes cell proliferation and oligodendroglial commitment in rat glial progenitor cells developing in vitro. J Neurosci Res 21:199-209.

Miano JM, Olson EN (1996) Expression of the smooth muscle cell calponin gene marks the early cardiac and smooth muscle cell lineages during mouse embryogenesis. J Biol Chem [Erratum (1997) 272:27492] 271:7095-7103.

Mujtaba T, Mayer-Proschel M, Rao MS (1998) A common neural progenitor for the CNS and PNS. Dev Biol 200:1-15.
Murphy M, Reid K, Dutton R, Brooker G, Bartlett PF (1997) Neural stem cells. J Investig Dermatol Symp Proc 2:8-13.

Nishida W, Kitami Y, Hiwada K (1993) cDNA cloning and mRNA expression of calponin and SM22 in rat aorta smooth muscle cells. Gene 130:297-302.

Nye JS, Kopan R, Axel R (1994) An activated Notch suppresses neurogenesis and myogenesis but not gliogenesis in mammalian cells. Development 120:2421-2430.

Owens GK (1995) Regulation of differentiation of vascular smooth muscle cells. Physiol Rev 75:487-517.

Peled A, Petit I, Kollet O, Magid M, Ponomaryov T, Byk T, Nagler A, Ben-Hur H, Many A, Shultz L, Lider O, Alon R, Zipori D, Lapidot T (1999) Dependence of human stem cell engraftment and repopulation of NOD/SCID mice on CXCR4. Science 283:845-848.

Petridou S, Maltseva O, Spanakis S, Masur SK (2000) TGF-beta receptor expression and smad2 localization are cell density dependent in fibroblasts. Invest Ophthalmol Vis Sci 41:89-95.

Pfrieger FW, Barres BA (1997) Synaptic efficacy enhanced by glial cells in vitro. Science 277:1684-1687.

Price J, Turner D, Cepko C (1987) Lineage analysis in the vertebrate nervous system by retrovirus- mediated gene transfer. Proc Natl Acad Sci USA 84:156-160.

Represa A, Trabelsi-Terzidis H, Plantier M, Fattoum A, Jorquera I, Agassandian C, Ben-Ari Y, der Terrossian E (1995) Distribution of caldesmon and of the acidic isoform of calponin in cultured cerebellar neurons and in different regions of the rat brain: an immunofluorescence and confocal microscopy study. Exp Cell Res 221:333-343.

Reynolds BA, Weiss S (1992) Generation of neurons and astrocytes from isolated cells of the adult mammalian central nervous system. Science 255:1707-1710.

Reynolds BA, Tetzlaff W, Weiss S (1992) A multipotent EGFresponsive striatal embryonic progenitor cell produces neurons and astrocytes. J Neurosci 12:4565-4574.

Richards LJ, Kilpatrick TJ, Dutton R, Tan SS, Gearing DP, Bartlett PF, Murphy M (1996) Leukaemia inhibitory factor or related factors promote the differentiation of neuronal and astrocytic precursors within the developing murine spinal cord. Eur J Neurosci 8:291-299.

Sanes JR, Rubenstein JL, Nicolas JF (1986) Use of a recombinant retrovirus to study post-implantation cell lineage in mouse embryos. EMBO J 5:3133-3142.

Schmitt-Graff A, Pau H, Spahr R, Piper HM, Skalli O, Gabbiani G (1990) Appearance of alpha-smooth muscle actin in human eye lens cells of anterior capsular cataract and in cultured bovine lens-forming cells. Differentiation 43:115-122.

Solway J, Seltzer J, Samaha FF, Kim S, Alger LE, Niu Q, Morrisey EE, Ip HS, Parmacek MS (1995) Structure and expression of a smooth muscle cell-specific gene, SM22 alpha. J Biol Chem 270:13460-13469.

Takahashi T, Nowakowski RS, Caviness Jr V (1995) The cell cycle of the pseudostratified ventricular epithelium of the embryonic murine cerebral wall. J Neurosci 15:6046-6057.

Temple S (1989) Division and differentiation of isolated CNS blast cells in microculture. Nature 340:471-473.

Temple S, Davis AA (1994) Isolated rat cortical progenitor cells are maintained in division in vitro by membrane-associated factors. Development 120:999-1008.

Trabelsi-Terzidis H, Fattoum A, Represa A, Dessi F, Ben-Ari Y, der Terrossian E (1995) Expression of an acidic isoform of calponin in rat brain: western blots on one- or two-dimensional gels and immunolocalization in cultured cells. Biochem J 306:211-215.

Verdi JM, Schmandt R, Bashirullah A, Jacob S, Salvino R, Craig CG, Program AE, Lipshitz HD, McGlade CJ (1996) Mammalian NUMB is an evolutionarily conserved signaling adapter protein that specifies cell fate. Curr Biol 6:1134-1145.

Walsh C, Cepko CL (1992) Widespread dispersion of neuronal clones across functional regions of the cerebral cortex. Science 255:434-440.

Williams BP, Read J, Price J (1991) The generation of neurons and oligodendrocytes from a common precursor cell. Neuron 7:685-693.

Zhong W, Feder JN, Jiang MM, Jan LY, Jan YN (1996) Asymmetric localization of a mammalian numb homolog during mouse cortical neurogenesis. Neuron 17:43-53.

Zhong W, Jiang MM, Weinmaster G, Jan LY, Jan YN (1997) Differential expression of mammalian Numb, Numblike and Notch1 suggests distinct roles during mouse cortical neurogenesis. Development 124: $1887-1897$. 